\title{
Shiftwork Association with Cardiovascular Diseases and Cancers Among Healthcare Workers: A Literature Review
}

\author{
Sağlık Çalışanlarında Nöbet Usulü Çalışmanın Kardiyovasküler \\ Hastalıklar ve Kanserler ile Ilisskisi: Bir Literatür Derlemesi
}

\author{
Adamu YAU $\odot$, Mainul HAQUE $\odot$
}

Ethics Committee Approval: Not Applicable. Conflict of interest: The authors have declared that they have no conflict of interest. Funding: None.

Informed Consent: Not Applicable.
Cite as: Yau A, Haque M. Shiftwork Association with Cardiovascular Diseases and Cancers among Healthcare Workers: A Literature Review. Medeniyet Med J. 2019;34:38795.

\begin{abstract}
The round-the-clock demands of healthcare services, coupled with the shortage of healthcare providers in many parts of the world, have made shiftwork widespread among healthcare workers. Understanding how to mitigate unfavourable effects of shiftwork on well-being is essential to improve health promotion, to prevent disease prevention, and to increase quality of life. This comprehensive review aims to present evidence linking shiftwork with cardiovascular diseases and cancers among healthcare workers. Several studies have demonstrated evidence indicating the relationship between long-term exposure to shiftwork tempo and a higher risk of cardiovascular diseases. Health workers are increasingly witnesing unfavourable effects of shiftwork on their health state. Shiftwork disturbs circadian rhythm and cardiopulmonary processes, leading to adverse health outcomes. Increasing prevalence of shiftwork in healthcare industries due to population expansion and public health threat of cancers call for investigation towards a better understanding of the underlying mechanism of shiftwork-induced diseases. The shift work period has been considered in different studies using various criteria, resulting in inconsistent definition of measurement criteria leading to misclassification of the study population. There is a need for a more considerable and holistic effort towards standardization of shiftwork definition and conduct an assessment to establish a more conveniently appliacable framework for intervention strategies.
\end{abstract}

Keywords: Shift work, rotating shiftwork, cardiovascular, cancers, healthcare

Öz

Sağlık hizmetlerinin gece gündüz aralıksız devam etmesi gerekliliği, dünyanın birçok yerinde sağlık hizmeti sunanların sayısındaki yetersizlik ile bir araya geldiğinde, gece nöbeti usulü çaıışmanın sağlık çalışanları arasında oldukça yaygın olmasına neden olmuştur. Nöbet usulü çalışmanın sağlık üzerine getirdiği olumsuz etkilerin nasıl azaltılabileceğini anlamak sağlığın daha iyi konuma getirilmesi, hastalıkların önlenmesi, ve yașam kalitesinin artması için șarttır. Bu kapsamlı derleme, sağlık çalışanlarında kardiyovasküler hastalıklar ve kanserlerin nöbet usulü çalışma ile bağlantısını ortaya koyan bulguları sunmayı amaçlamaktadır. Birçok çalışma uzun süredir nöbet usulü çalışma temposuna maruz kalmak ile kardiyovasküler hastalıklara yakalanma riski arasında bağlantı olduğunu göstermiştir. Sağlık çalışanları, nöbet usulü çalışmaya bağlı gelişen sağlıkları üzerindeki olumsuz etkilere giderek daha çok şahit olmaktadırlar. Nöbet usülü çalışmak, sirkadiyan ritmi ve ve kardiyopulmoner süreçleri bozarak olumsuz sağlık sonuçlarına sebep olur. Popülasyondaki büyümeye bağlı olarak sağllk hizmeti birimlerinde nöbet usulü çalışma sisteminin sıklığının artması ve kanserlerin halk sağlığı üzerindeki tehdidinin artması, nöbet usulü çalışmanın tetiklediği hastalıkların altında yatan mekanizlamarı daha iyi anlamak için araştırmalar yapılmasına ihtiyaç doğurmuştur. Nöbet usulü çalışılan süre farklı çalışmalarda çeşitli kritlerler kullanılarak göz önüne alınmıştır, ancak bu durum ölçümün tanımlanmasında tutarsızlığa ve sonuç olarak da çalıșma popülasyonunun yanlıs olarak sınıflandırılmasına yol açmıștır. Nöbet usulü çalıșmanın tanımını standardize etmek için daha büyük ve bütünsel bir çabaya ihtiyaç olup girişim stratejileri için daha uygulanması müsait bir çerçeve kurmak gereklidir.

Anahtar kelimeler: Vardiyalı çalışma, rotasyonlu vardiya, kardiyovasküler, kanser, sağlık hizmeti

(c) Copyright Istanbul Medeniyet University Faculty of Medicine. This journal is published by Logos Medical Publishing.

Licenced by Creative Commons Attribution-NonCommercial 4.0 International (CC BY-NC 4.0)
Received: 27 June 2019

Accepted: 13 September 2019 Online First: 26 December 2019

Corresponding Author: M. Haque

ORCID: 0000-0002-6124-7993 Universiti Pertahanan Nasional Malaysia, Faculty of Medicine and Defence Health, Department of Pharmacology, Kem Perdana Sungai Besi, 57000 Kuala Lumpur, Malaysia

runurono@gmail.com

A. Yau

ORCID: 0000-0003-2388-1085

Naresuan University, Faculty of Pharmaceutical Sciences, Phitsanulok, Thailand

Texas A\&M University, School of Public Health, Health Science Center, Department of Epidemiology and Biostatistics, Texas, USA.

Bayero University, Faculty of Pharmaceutical Sciences, Department of Pharmacology and Therapeutics, Kano, Nigeria 


\section{INTRODUCTION}

The healthcare sector has been one of the fastest-growing economies among the working industries. On average, the section employs 18 million personnel in the United States alone. It is essential that healthcare services is provided continuously,so shiftwork is among the core components of the healthcare service. The round-theclock demands of healthcare services, coupled with the shortage of healthcare providers in many parts of the world, has led to widespread use of shiftwork among healthcare workers. According to the third European Union (EU) Survey conducted in 2000, three-fourths of employers worked longer than the regularly scheduled time ${ }^{1,2}$. The prevalence rates of shiftwork exposure were 21.9, and $10.7 \%$ in men and women, respectively, while permanent night shiftwork exposure was $7 \%$ among working population ${ }^{3}$. Shiftworkassociated adverse health effects include, among others; shiftwork disorders, cognitive impairment, cardiovascular risk, increased risks of cancers, and diabetes ${ }^{4-8}$. Shiftwork alters the body's biological clock resulting in physical, clinical, and psychiatric symptoms ${ }^{1,9}$. Understanding how to mitigate health effects associated with shiftwork is essential for the promotion of public health, disease prevention, and improvement of quality of life. This comprehensive review aims to present evidence linking shiftwork with cardiovascular diseases, and cancers among healthcare workers. We have also highlighted some interventions to alleviate the problems.

\section{MATERIALS and METHODS}

Search Strategy: A literature search was performed using the PubMed database from its inception to February 2019. The following search terms were used to find eligible studies; [" "shift work" OR "night shift" OR "rotation work" OR "shiftwork rotation") AND ("cardiovascular disease” OR cardiovascular OR stroke OR "heart disease" OR "myocardial infarction" OR "angina pec- toris")) AND (cancer* OR tumor OR)))]. This paper reported the summary findings of the included relevant articles.

Data Extraction: The authors conducted a literature search systematically but screened the relevant studies from the retrieved articles in a snowball manner. The authors extracted data based on the relevance of study to the topic under review. The summary of the included studies is in the result section below.

\section{RESULTS and DISCUSSION}

Shiftwork Exposure: There has been an increasing body of evidence concerning the association between shiftwork and adverse health effects among healthcare workers. Healthcare workers are faced with a number of occupational hazards leading to health problems, such as violence, physical injuries, psychological stress, exposure to chemicals and infectious agents, latex allergy, back and musculoskeletal disorders ${ }^{1,2,10,11}$. A study conducted by the American Nurses Association demonstrated that exposure to occupational hazard, health, and safety were the major concerns among $88 \%$ of 4.826 participants. These major concerns significantly influence nurses' decision to perform a particular task and whether to remain in the profession ${ }^{4}$. Furthermore, only less than one-fifth of the participants reported being safe from exposure to occupational hazards in their workplace. Physical assaults such as exposure to verbal abuse and threats while on duty were reported in $17 \%$ and $56.9 \%$ of the participants, respectively. Approximately $70 \%$ of the participants were exposed to either acute or chronic effects of stress during shift work. More than two-thirds (69.4\%) of the participants had disabled back injuries. However, the prevalence of exposure to infectious sources was $45.4 \%$ for Human Immunodeficiency Virus (HIV) or Hepatitis, while it was $37.4 \%$ for tuberculosis or needle-stick related infections. Other reported exposures to occupational hazards include, exposure to workplace assault (24.7\%), 
and latex allergy (20.9\%). After a decade, the American Nurses Association also investigated the prevalence of occupational exposure to hazardous agents among nurses ${ }^{1}$. Findings from the second study demonstrated that there was an improvement in the work schedules. However, the prevalence of exposure to shiftwork -related stressors increased. The reported prevalence rates were $74 \%$ for stress and fatigue exposure, $62 \%$ for disabling musculoskeletal diseases, and $82 \%$ for work stress. Furthermore, concerns about exposure to infectious agents remains at $43 \%{ }^{1}$. Similarly, another study conducted on 100 female hospital staff, and including 511 observations, found significant evidence of shiftwork exposure and its adverse health effects ${ }^{12}$.

\section{Health outcomes}

Shiftwork disturbs the circadian rhythm, leading to a decrease in nocturnal melatonin production and its subsequent release. The impact of the night shift leads to either short-term or long-term effects. The short-term consequence of night shift is known as "jet-lag effects," and it is characterized by emotional fluctuations, indigestion, anxiety, insomnia, fatigue, and declining physical activity. The long-term effect results in numerous health outcomes, such as metabolic disorders, cardiovascular diseases, neurological and neurodegenerative disorders, reproductive problems, and cancers ${ }^{13-17}$. Several studies were conducted with the primary objective to investigate the adverse health outcomes associated with exposure to shift work.

\section{Exposure to Shiftwork and Cardiovascular Disease}

Exposure to shiftwork disrupts sleep patterns and circadian rhythm resulting in an increase in sympathetic activity and hyperproduction of inflammatory cytokines ${ }^{5,18-20}$. This disruption leads to the dysregulation of lipid and neuroendocrine systems, cardiometabolic disorders, and hyper- tension among shift workers ${ }^{21}$.

A hemostatic balance between the parasympathetic and sympathetic activity of the autonomous nervous system (ANS) is necessary for a healthy cardiovascular system. The functional state of the cardiovascular system determines the performance of the cardiopulmonary system, and both systems operate with regular circadian patterns. Their circadian rhythms can be measured by monitoring heart rates and blood pressure ${ }^{22}$. In normal physiological conditions, the average heart rate is decreased at night compared to daytime, gradually increases in the early morning, reaches an apex at about noon, and then starts declining towards the end of the daytime ${ }^{23}$. This physiological pattern is essential for normal physiological processes. The cardiovascular disturbances such as sudden cardiac death, embolism, stroke, and myocardial infarction and their subsequent risks also follow similar patterns of circadian rhythms, with a a gradual increase in severity in the early morning compared to night period ${ }^{22,24}$. Therefore, circadian rhythms influence cardiopulmonary processes. Irregular work patterns or shiftwork disturb circadian rhythms leading to an adverse health outcome in individuals trying physiologically to synchronize shiftwork with circadian processes. Boudreau et al. ${ }^{25} 2013$ investigated the effects of circadian adaptation to night shiftwork on performance, alertness, sleep, mood, and cardiac autonomic responses in night shift workers $(n=15)$. Findings from this study have demonstrated that thanks to physiologically adapted circadian rhythm night shift workers tend to perform better, be alert, and have a better mood, and less sympathetic firing during sleep than in-circadian-adapted group after seven consecutive night shifts. The investigators concluded that the failure of circadian synchronization with night shiftwork is associated with different adverse health outcomes. Similarly, numerous studies have reported a plausible relationship between longterm exposure to shiftwork and the higher risk of cardiovascular diseases ${ }^{18,21,26}$. Other studies have investigated the effects of sleep disturbances and 
shiftwork on heart rate variability and other autonomic physiological responses ${ }^{27-29}$. The heart rate variability has been used as a non-invasive marker of circadian-shiftwork adaptation processes ${ }^{25,30,31}$. This non-invasive biomarker has been proven to be valid and its use can be extended to the cardiopulmonary system to study long-term effects ${ }^{32-34}$.

A balanced ANS activity in the cardiopulmonary cycles is critical for maintaining homeostasis and normal physiological function. Stimulating vagal parasympathetic activity and HRV have been suggested as intervention points to improve health outcomes and prevent adverse health effects, including the risk of mortality ${ }^{35,36}$. An increasing body of evidence suggested that interventions targeting Heart Rate Variability (HRV) coherence among shift workers could reduce their shiftwork -related adverse health effects. Specifically, improvement in symptoms such as anxiety, stress, depression, cognitive issues, and sleep was postulated indices demonstrating better health outcomes $^{37-39}$.

Moreover, findings from another cohort study showed a significant association between exposure to shiftwork and a higher risk of type 2 diabetes $^{16}$. Exposure to shiftwork was found to be associated with 13,40 , and $40 \%$ increases in the risks of type 2 diabetes, for 5, 10-19, and more than 20 years of exposure to shift work, respectively. None of the adjusted confounding factors were found to abate the risk ${ }^{16}$. Another prospective cohort study with 189,158 women followed up over 24 years was conducted to investigate the association between night shiftwork and the risk of Coronary Heart Diseases (CHD) ${ }^{17}$. It was also shown that night shiftwork was associated with a significantly higher risk of CHD among nurses compared to unexposed nurses. The duration of exposure to shiftwork was significantly associated with a higher risk of CHD in a dose-response manner. Furthermore, a time-dependent association has been demonstrated between duration since quitting the exposure to shiftwork and the lower risk of developing CHD. Compared to the unexposed group the risk of developing CHD decreased $15 \%$, and $13.1 \%$ for every 5-9 years, and more than 24 years since quitting shiftwork ${ }^{17}$.

\section{Shiftwork and Cancers}

The presence of a significant positive association between work shift exposures and different cancer types has been investigated among healthcare workers over the past decade. For example, five years of shiftwork exposure was associated with a $3.3 \%(95 \% \mathrm{Cl}, 1.012-1.056)$ increase in the risk of breast cancer ${ }^{40}$. This dose-response relationship has been reported from numerous epidemiological studies ${ }^{40}$. Similarly, dose-response relationships have been established between exposure to night shiftwork and skin cancer, lung cancer, and digestive system cancers ${ }^{41-43}$. However, night shiftwork exposure was not significantly associated with ovarian and cervical cancers ${ }^{44}$. Furthermore, another study revealed that long-term exposure to night work shift is attributed to $57.7 \%$ and a $28 \%$ increase in the risk of breast cancer and lung cancer, respectively ${ }^{45}$.

The underlying mechanisms that mediate the effects of shiftwork on health effects are largely unknown. Several dimensions have been explored to better understand the circumstances surrounding shiftwork-induced health effects. Socio-behavioral factors significantly influence the association between exposure to shiftwork and adverse health outcomes. Healthcare workers exposed to shiftwork are more likely to gain a higher Body Mass Index (BMI) compared to unexposed. BMI has been implicated in many metabolic disorders such as diabetes, and this may shed more light on the current understanding of the underlying mechanism of shiftwork-related health outcomes. A dose-response relationship between duration of exposure to shiftwork and changes in BMI has been reported ${ }^{16,46}$. It has been demonstrated that every 5-year-increase in exposure to shiftwork was significantly associated with a 0.17 unit in- 
crease in BMI among nurses ${ }^{16,46}$. Moreover, another study ( $\mathrm{n}=1163$ nurses) revealed a significant association between working for more than 12 hours per day combined with working for more than 40 hours per week and a higher risk of musculoskeletal diseases. The authors measured the psychological demands using the validated Job Control Questionnaire ${ }^{34,47}$. The risk of musculoskeletal diseases decreased by 50\% when the researchers adjusted shiftwork for psychological and physical job demands. Therefore, psycho-physical components are important intervention points for addressing the risk of musculoskeletal diseases associated with exposure to shiftwork ${ }^{15,48}$.

There has been a plausible relationship between melatonin and circadian rhythms. This melatonincircadian relationship alters the oxidative stress balance, immune system, antiangiogenesis, and other processes of carcinogenesis ${ }^{49}$. During the night, melatonin levels are low, particularly among night shift workers ${ }^{50,51}$. Numerous studies demonstrated low levels of melatonin in lung ${ }^{52}$, breast ${ }^{51}$, ovarian $^{49}$, prostate $^{53}$, gastrointestinal ${ }^{54}$, and skin cancer. The pathophysiology of shiftwork-induced cancers could be attributed to the observed suppression of melatonin level and hormonal imbalance in night shift workers and cancer patients, respectively. The overall mechanism underlying the molecular and hormonal basis of shiftworkrelated diseases has been proposed to be systemic, not local. However, organ-specific cancers were reported among shift workers, compared to non-shift workers ${ }^{41,42,55-58}$. An increasing body of evidence demonstrates the association between shiftwork and the risk of prostate cancers, albeit contradictory findings ${ }^{59}$.

One of the postulated mechanisms of shiftworkrelated cancers is that night shiftwork alters circadian rhythm leading to an increase in sex hormones. Increase in sex hormones has been implicated in hormone-dependent cancers ${ }^{60}$. Secondly, exposure to light during night shiftwork disrupts circadian rhythm leading to low produc- tion of melatonin ${ }^{61}$. Oncostatic effects of melatonin are protective against sensitive cancers ${ }^{62}$. Reduction in melatonin production in people exposed to light increases risks of cancers by stimulating the production of pituitary gonadotropins via negative feedback mechanism ${ }^{63}$. Several in vitro and in vivo studies have demonstrated the roles of melatonin in cancer protection and inhibition $^{64-73}$. Another postulated pathway is that night shiftwork reduces sunlight exposure leading to a low level of vitamin D. Several epidemiological and experimental studies have demonstrated that low level of vitamin D was associated with the risks of cancers ${ }^{74-77}$. The essential nature of health care sectors makes healthcare workers work in a 24-hour mode, not the routine 8-hour-schedule.

Most of the studies that have reported a significant increase in the risks of cancers, such as digestive cancers, breast cancers, and lung cancers in nurses, were characterized by a limited sample size. Many of the published studies among healthcare workers were conducted among nurses ${ }^{44}$. Future studies should involve a large sample size, multiple disciplines of healthcare, and numerous centers or regions to improve the generalizability of findings to policy development in public health. Another significant result from our review is the presence of distinct variations in the definition of night shift work. Different studies considered shiftwork periods differently using various criteria, resulting in inconsistent definitions based on diverse measurement methods of shift work. This inconsistency might have contributed to the misclassification of the study population. Greater number of significant efforts are needed towards standardization of shiftwork definition, and assessment of its effects to establish an applicable intervention framework. Increasing prevalence of shiftwork in healthcare industries due to population expansion and its public health threats call for further investigation towards shiftworkinduced cancers. The bioinformatics and system biology approaches may be promising pathways toward a better understanding of the relation- 
ships between shiftwork exposures and the risks of cancers in healthcare workers and the general population. Establishing how shiftwork mediates cancer risk could offer promising intervention points and help establish effective strategies towards prevention and improving public health. Routine cancer screenings, physical and medical examination of shift workers would provide opportunities for early detection and a better understanding of first exposure to shift work, especially among long-term night shift workers.

\section{Proposed Interventions}

Several interventions have been suggested based on the major factors mediating the shiftwork associated with health effects. Three major factors available in the literature include physical stressors such as fatigue, violence, and stress. The second category of factors is psychological factors such as irregular sleep patterns and body's response to other stressors. The third is sociobehavioral stressors such as body mass index and diet behaviors. Several interventions have been proposed to mitigate the listed factors. One of the proposed interventions was napping. Providing time to take a short nap in between or during shiftwork could be a crucial intervention. This could reduce sleep deprivation and lowers sleep inertia leading to improved mental and psychological alertness during shift work. A cross-over study investigated the effectiveness of 20-minute nap between periods of shift works. Their findings demonstrated that taking a nap for a 20minute daytime was significantly associated with improved vigilant performance among workers. Furthermore, their findings revealed that taking a nap for about 20-30 minutes during the night shift was significantly associated with improved performance during shiftwork ${ }^{78}$. Also adjustment of work schedules was proposed as a measure to mitigate shiftwork-related adverse health effects. Revision of scheduling policies to capture all the stakeholders proved effective. A participatory work schedule significantly supports shift workers during adjustment of their circadian clock towards adaptation of nightshiftwork ${ }^{79}$. Abrupt changes in the work schedule have been highly discouraged. The time interval between one shift and another should allow workers to have minimum recommended sleep for average healthy adults. For example, closing shift late evening and reporting on duty at 7 or 8 the following day deprive worker of having enough sleep. Among healthcare workers, an average of at least eleven hours of sleep has been suggested between one shift and another ${ }^{80,81}$. Thirdly, psychological, and behavioral measures have been proposed. Some researchers explored the use of Cognitive and Behavioral Therapy (CB-T) towards the mitigation of health disorders associated with exposure to shift work. The CB-T strategy seems promising, and further studies are needed to fully reap the results of its potential application in this regard ${ }^{82,83}$.

\section{SUMMARY and CONCLUSION}

The available evidence demonstrates that exposure to night shiftwork is associated with cardiovascular and cancer risks among healthcare workers. Four postulated biological mechanisms underlying the pathophysiology of shiftworkrelated cardiovascular diseases and cancers are available in the literature. The first mechanism is the disruption of regular circadian cycles and biological clock, leading to sleep disorders, eating problems, and subsequent adverse health effects. Melatonin regulation pathway was the second postulated molecular mechanism implicated in many shifts work-related to adverse health effects, including cancers and cardiovascular diseases, among others. A better understanding of the mechanistic pathways of shiftwork-related diseases is essential for improvement of public health and quality of life.

The third postulated pathway is decreased exposure to sunlight that has been reported among night shift workers. Reduced sunlight exposure is known to cause a decrease in vitamin D levels, a 
documented risk factor for prostate cancer, and may also contribute to other adverse health outcomes and quality of life. Fourthly, the effects of night shiftwork on sex hormones have been implicated in the underlying pathophysiology of shiftwork associated with cancers and cardiovascular diseases. Plausible epidemiological evidence coupled with findings from in vitro and in vivo studies support the role of this pathway. There are inconsistent findings in some shiftwork-related cancers and subclinical cardiovascular effects. Generally, greater number of well-designed epidemiological studies with larger sample size and long-term follow up are required to further evaluate the causal relationship between exposure to shiftwork and health outcomes, including cancer and cardiovascular diseases. The findings presented here are not exhaustive, and it is imperative to state that collaborative efforts from the employees, employers, policymakers and the management team is required to mitigate the adverse health effects associated with exposure to shift work.

\section{Acknowledgments}

The authors appreciate the consultants at the University Writing Center (UWC), Texas A\&M University-College Station, Texas, USA for taking their time to review grammar and clarity of this paper. YA acknowledged the management of Naresuan University-Thailand (Naresuan University International Scholarship), Bayero University Kano, Nigeria, as well as the former governor of Kano State, Senator. Rabiu Musa Kwankwaso for providing necessary support to produce this work.

\section{REFERENCES}

1. Costa G. Shiftwork and occupational medicine: an overview. Occup Med (Oxford, England). 2003;53:83-8. [CrossRef]

2. Costa G, Åkerstedt T, Nachreiner F et al. Flexible working hours, health, and well-being in Europe: some considerations from a SALTSA project. Chronobiol Int. 2004;21:831-44. [CrossRef]

3. Parent-Thirion A, Fernández Macías E, Hurley J et al. Fourth European working conditions survey, European Foundation for the improvement of living and working conditions. Luxembourg: Office for Official Publications of the European Communities 2007: 37-61.

4. Cancer IAfRo. Painting, firefighting, and shiftwork: IARC monographs on the evaluation of carcinogenic risks to humans, v. 98. World Health Organization (WHO) Lyon, France, 2010: 764.

5. Caruso CC. Negative impacts of shiftwork and long work hours. Rehabilitation nursing: the official journal of the Association of Rehabilitation Nurses. 2014;39:16-25. [CrossRef]

6. Folkard S, Lombardi DA, Tucker PT. Shiftwork: safety, sleepiness, and sleep. Industrial Health. 2005;43:20-3. [CrossRef]

7. Videnovic A, Zee PC. Consequences of Circadian Disruption on Neurologic Health. Sleep Med Clin. 2015;10:46980. [CrossRef]

8. Faraut B, Bayon V, Leger D. Neuroendocrine, immune and oxidative stress in shift workers. Sleep Medicine Reviews. 2013;17:433-44. [CrossRef]

9. Akerstedt T. Shiftwork and disturbed sleep/wakefulness. Occupational medicine (Oxford, England). 2003;53:8994. [CrossRef]

10. ANA. Health \& Safety Survey - American Nurses Association. http://www.nursingworld.org/hssurvey-2011.

11. Costa G. Shiftwork and health: current problems and preventive actions. Saf Health Work. 2010;1:112-23. [CrossRef]

12. Rabstein S, Burek K, Lehnert M et al. Differences in twenty-four-hour profiles of blue-light exposure between day and night shifts in female medical staff. Sci Total Environ. 2019;653:1025-33. [CrossRef]

13. Brown DL, Feskanich D, Sanchez BN et al. Rotating night shiftwork and the risk of ischemic stroke. Am J Epidemiol. 2009; 169:1370-7. [CrossRef]

14. Lieu SJ, Curhan GC, Schernhammer ES et al. Rotating night shiftwork and disparate hypertension risk in AfricanAmericans. J Hypertension. 2012;30:61-6. [CrossRef]

15. Lipscomb JA, Trinkoff AM, Geiger-Brown J et al. Workschedule characteristics and reported musculoskeletal disorders of registered nurses. Scandinavian Journal of work, Environment \& Health. 2002;28:394-401. [CrossRef]

16. Pan A, Schernhammer ES, Sun $Q$ et al. Rotating night shiftwork and risk of type 2 diabetes: two prospective cohort studies in women. PLoS Med. 2011;8:e1001141. [CrossRef]

17. Vetter C, Devore EE, Wegrzyn LR et al. Association Between Rotating Night Shiftwork and Risk of Coronary Heart Disease Among Women. Jama. 2016;315:172634. [CrossRef]

18. Puttonen S, Viitasalo K, Harma M. Effect of shiftwork on systemic markers of inflammation. Chronobiol Int. 2011;28:528-35. [CrossRef]

19. Irwin MR, Olmstead R, Carroll JE. Sleep Disturbance, Sleep Duration, and Inflammation: A Systematic Review and Meta-Analysis of Cohort Studies and Experimental Sleep Deprivation. Biological Psychia. 2016;80:40-52. [CrossRef]

20. Dettoni JL, Consolim-Colombo FM, Drager LF et al. Cardiovascular effects of partial sleep deprivation in healthy volunteers. J. applied physio (Bethesda, Md: 1985). 2012;113:232-6. [CrossRef]

21. Reutrakul S, Knutson KL. Consequences of Circadian Disruption on Cardiometabolic Health. Sleep Med Clinics. 2015;10:455-68. [CrossRef]

22. Takeda N, Maemura K. Circadian clock and the onset of 
cardiovascular events. Hypertension research: official J Japanese Society of Hypertension. 2016;39:383-90. [CrossRef]

23. Portaluppi F, Tiseo R, Smolensky $\mathrm{MH}$ et al. Circadian rhythms and cardiovascular health. Sleep Medicine Reviews. 2012;16:151-66. [CrossRef]

24. Manfredini R, Boari B, Smolensky $\mathrm{MH}$ et al. Circadian variation in stroke onset: identical temporal pattern in ischemic and hemorrhagic events. Chronobiol Int. 2005;22:417-53. [CrossRef]

25. Boudreau P, Dumont GA, Boivin DB. Circadian adaptation to night shiftwork influences sleep, performance, mood, and the autonomic modulation of the heart. PloS one. 2013;8:e70813. [CrossRef]

26. Wang XS, Armstrong ME, Cairns BJ, et al. Shiftwork and chronic disease: the epidemiological evidence. Occup Med (Oxford, England). 2011;61:78-89. [CrossRef]

27. Souza BB, Monteze NM, de Oliveira FL et al. Lifetime shiftwork exposure: association with anthropometry, body composition, blood pressure, glucose, and heart rate variability. Occup Environ Med. 2015;72:208-15. [CrossRef]

28. Togo F, Takahashi $M$. Heart rate variability in occupational health --a systematic review. Ind Health. 2009;47:589602. [CrossRef]

29. Jarczok MN, Jarczok M, Mauss D et al. Autonomic nervous system activity and workplace stressors--a systematic review. Neuroscience and Biobehavioral Reviews. 2013;37:1810-23. [CrossRef]

30. Chung $\mathrm{MH}$, Kuo TB, Hsu $\mathrm{N}$ et al. Sleep and autonomic nervous system changes - enhanced cardiac sympathetic modulations during sleep in permanent night shift nurses. Scandinavian journal of Work, Environment \& Health. 2009;35:180-7. [CrossRef]

31. Chung MH, Kuo TB, Hsu N et al. Recovery after threeshift work: relation to sleep-related cardiac neuronal regulation in nurses. Industrial Health. 2012;50:24-30. [CrossRef]

32. Jarvelin-Pasanen S, Ropponen A, Tarvainen MP et al. Differences in heart rate variability of female nurses between and within normal and extended work shifts. Industrial Health. 2013;51:154-64. [CrossRef]

33. Ito $H$, Nozaki $M$, Maruyama $T$, et al. Shiftwork modifies the circadian patterns of heart rate variability in nurses. Int J Cardio. 2001;79:231-6. [CrossRef]

34. Huang GD, Feuerstein M, Sauter SL. Occupational stress and work-related upper extremity disorders: concepts and models. AJIM. 2002;41:298-314. [CrossRef]

35. Dunlap ME, Bhardwaj A, Hauptman PJ. Autonomic Modulation in Heart Failure: Ready for Prime Time? Cardio Reports. 2015;17:103. [CrossRef]

36. Garcia AJ, 3rd, Koschnitzky JE, Dashevskiy T et al. Cardiorespiratory coupling in health and disease. Autonomic neuroscience: Basic \& Clinical. 2013;175:26-37. [CrossRef]

37. Lehrer PM. Heart rate variability biofeedback and other psychophysiological procedures as important elements in psychotherapy. Int j psychophysiol: official journal of the Int Organization of Psychophysiology. 2018;131:8995. [CrossRef]

38. Goessl VC, Curtiss JE, Hofmann SG. The effect of heart rate variability biofeedback training on stress and anxiety: a meta-analysis. Psychol Med. 2017;47:2578-86. [CrossRef]
39. Lehrer PM, Gevirtz R. Heart rate variability biofeedback: how and why does it work? Front in Psychol. 2014;5:756. [CrossRef]

40. Wang F, Yeung K, Chan W, et al. A meta-analysis on dose-response relationship between night shiftwork and the risk of breast cancer. Ann Oncol. 2013;24:2724-32. [CrossRef]

41. Kamdar BB, Tergas AI, Mateen FJ et al. Night-shiftwork and risk of breast cancer: a systematic review and meta-analysis. Breast cancer Res Treat. 2013;138:291-301. [CrossRef]

42. Mancio J, Leal $C$, Ferreira $M$, et al. Does the association of prostate cancer with night-shiftwork differ according to rotating vs. fixed schedule? A systematic review and meta-analysis. Prostate Cancer Prost Dis. 2018;21:33744. [CrossRef]

43. Wang X, Ji A, Zhu Y et al. A meta-analysis including the dose-response relationship between night shiftwork and the risk of colorectal cancer. Oncotarget. 2015;6:25046. [CrossRef]

44. Liu W, Zhou Z, Dong D et al. Sex Differences in the Association between Night Shiftwork and the Risk of Cancers: A Meta-Analysis of 57 Articles. Dis Mmarkers. 2018; 2018. [CrossRef]

45. Yuan X, Zhu C, Wang M et al. Night Shiftwork Increases the Risks of Multiple Primary Cancers in Women: A Systematic Review and Meta-analysis of 61 Articles. Cancer epidemiology, biomarkers \& prevention : a publication of the American Association for Cancer Research, cosponsored by the American Society of Preventive Oncology. 2018;27:25-40. [CrossRef]

46. Burch JB, Alexander M, Balte $P$ et al. Shiftwork and Heart Rate Variability Coherence: Pilot Study Among Nurses. Appl Psychophysiol Biofeedback. 2019;44:2130. [CrossRef]

47. Riley MW, Hung YT, Wang MJ et al. Interactions between task repetition and psychosocial factors. Work (Reading, Mass). 2012; 41(Suppl 1):2392-7.

48. Isabella Z, Fiona B, Catherine T. Shiftwork and work-related injuries among health care workers: A systematic review. Aust J Adv Nur. 2010;27:62.

49. Zhao $M$, Wan J, Zeng $K$, et al. The reduction in circulating melatonin level may contribute to the pathogenesis of ovarian cancer: a retrospective study. J Cancer. 2016;7:831. [CrossRef]

50. Mirick DK, Bhatti P, Chen C et al. Night-shiftwork and levels of 6-sulfatoxymelatonin and cortisol in men. Cancer Epi Prevent Biomark. 2013;22:1079-87. [CrossRef]

51. Davis S, Mirick DK, Chen C, et al. Night-shiftwork and hormone levels in women. Cancer Epidemiol. Prev Biomarkers. 2012;21:609-18. [CrossRef]

52. Lissoni P, Chilelli $M$, Villa $S$ et al. Five years survival in metastatic non-small cell lung cancer patients treated with chemotherapy alone or chemotherapy and melatonin: a randomized trial. J Pineal Res. 2003;35:12-5. [CrossRef]

53. Rodriguez-Garcia A, Mayo JC, Hevia D et al. Phenotypic changes caused by melatonin increased sensitivity of prostate cancer cells to cytokine-induced apoptosis. J Pineal Res. 2013;54:33-45. [CrossRef]

54. Persson C, Glimelius B, Rönnelid J et al. Impact of fish oil and melatonin on cachexia in patients with advanced gastrointestinal cancer: a randomized pilot study. Nutrition. 2005;21:170-8. [CrossRef] 
55. Lee H-E, Lee J, Jang T-W, et al. The relationship between night work and breast cancer. Ann Occup Environ Med. 2018;30:11. [CrossRef]

56. He C, Anand ST, Ebell MH, et al. Circadian disrupting exposures and breast cancer risk: a meta-analysis. Int Arch Occup Enviro Health. 2015;88:533-47. [CrossRef]

57. Gan Y, Li L, Zhang L et al. Association between shiftwork and risk of prostate cancer: a systematic review and meta-analysis of observational studies. Carcinogenesis. 2017;39:87-97. [CrossRef]

58. Du H-B, Bin K-Y, Liu W-H et al. Shift work, night work, and the risk of prostate cancer: a meta-analysis based on 9 cohort studies. Medicine. 2017; 96. [CrossRef]

59. Rao D, Yu H, Bai Y et al. Does night-shiftwork increase the risk of prostate cancer? a systematic review and metaanalysis. Onco Targets Ther. 2015;8:2817-26. [CrossRef]

60. Schernhammer ES, Rosner B, Willett WC, Laden F, Colditz GA, Hankinson SE. Epidemiologyofurinarymelatonininwomenanditsrelationtoother hormones and night work. Cancer Epidemiol Biomarkers Prev. 2004;13:936-43.

61. Straif K, Baan R, Grosse Y, Secretan B, Ghissassi FE, Bouvard V, et al. Carcinogenicity of shift-work, painting, and fire-fighting. Lancet Oncol. 2007;8:1065-6. [CrossRef]

62. Viswanathan AN, Schernhammer ES. Circulating melatonin and the risk of breast and endometrial cancer in women. Cancer Lett 2009; 281:1-7. [CrossRef]

63. Davis S, Mirick DK. Circadian disruption, shift work and the risk of cancer: a summary of the evidence and studies in Seattle. Cancer Causes Control. 2006;17:539-45. [CrossRef]

64. El-Aziz MAA, Hassan HA, Mohamed MH, Meki ARMA, Abdel-Ghaffar SKH, Hussein MR. The biochemical and morphological alterations following administration of melatonin, retinoic acid and Nigellasativa in mammary carcinoma: an animal model. Int J Exp Pathol. 2005;86:38396. [CrossRef]

65. Hill SM, Blask DE. Effects of the pineal hormone melatonin on the proliferation and morphological characteristics of human breast cancer cells (MCF-7) in culture. Cancer Res. 1988;48:6121-6.

66. Cos S, Fernandez F, Sanchez-Barcelo EJ. Melatonininhibitsdnasynthesis in mcf-7 human breast cancer cells in vitro. Life Sci. 1996;58:2447-53. [CrossRef]

67. Mediavilla MD, Cos S, Sanchez-Barcelo EJ. Melatonin increases p53 and p21WAFl expressionin MCF-7 humanbreastcancercellsinvitro.Life Sci. 1999;65:415-20. [CrossRef]

68. Cos S, Mediavilla MD, Fernandez R, Gonzalez-Lamu no $D$, Sanchez-Barcelo EJ. Does melatonin induce apoptosis in MCF-7 human breast cancer cells in vitro? J Pineal Res. 2002;32:90-6. [CrossRef]

69. Ying SW, Niles LP, Crocker C. Humanmalignant melanoma cellsexpress high-affinity receptors for melatonin: antiproliferative effects of melatonin and 6-chloromelatonin. Eur J Pharmacol. 1993;246:89-96. [CrossRef]
70. Sze SF, Ng TB, Liu WK. Antiproliferative effect of pineal indoles on cultured tumor cell lines. J Pineal Res. 1993;14:27-33. [CrossRef]

71. Shiu SYW, Li L, Xu JN, Pang CS, Wong JTY, Pang SF. Melatonin-induced inhibition of proliferation andG1/Scellcycletransitiondelayofhuman choriocarcinoma JAr cells: possible involvement of MT 2 (MEL(1B)) receptor. J Pineal Res. 1999;27:183-92. [CrossRef]

72. Petranka J, Baldwin W, Biermann J, Jayadev S, Barrett JC, Murphy E. The oncostatic actionof melatonin inanovarian carcinomacellline. J Pineal Res. 1999;26:129-36. [CrossRef]

73. Kanishi Y, Kobayashi Y, Noda S, Ishizuka B, Saito K. Differential growth inhibitory effect of melatonin on two endometrial cancer cell lines. J Pineal Res. 2000;28:227-33. [CrossRef]

74. Welsh J. Vitamin D and breast cancer: insights from animal models. Am J Clin Nutr. 2004;80(6 Suppl):1721S-4S. [CrossRef]

75. Bauer SR, Hankinson SE, Bertonejohnson ER, Ding EL. Plasmavitamin D levels, menopause, and risk of breast cancer: dose-response meta-analysis of prospective studies. Medicine. 2013;92:123-31. [CrossRef]

76. Chandler PD, Buring JE, Manson JE, Giovannucci EL, Moorthy MV, Zhang S, et al. Circulating vitamin D levels and risk of colorectal cancer in women. Cancer Prev Res. 2015;8:675-82. [CrossRef]

77. Ward M, Berry DJ, Power C, Hypp€onen E. Working patterns and vitamin D status in mid-life: a cross-sectional study of the 1958 British birth cohort. Occup Environ Med. 2011;68:902-7. [CrossRef]

78. Rajaratnam SM, Howard ME, Grunstein RR. Sleep loss and circadian disruption in shift work: health burden and management. The Med J Aust. 2013;199:S11-5. [CrossRef]

79. Smith MR, Eastman CI. Shift work: health, performance and safety problems, traditional countermeasures, and innovative management strategies to reduce circadian misalignment. Nat Sci Sleep. 2012;4:111-32. [CrossRef]

80. Richter K, Acker J, Adam S et al. Prevention of fatigue and insomnia in shift workers-a review of non-pharmacological measures. The EPMA J. 2016;7:16. [CrossRef]

81. Knauth P, Hornberger S. Preventive and compensatory measures for shift workers. Occup Med (Oxford, England). 2003;53:109-16. [CrossRef]

82. Jarnefelt $H$, Sallinen $M$, Luukkonen $R$ et al. Cognitive behavioral therapy for chronic insomnia in occupational health services: analyses of outcomes up to 24 months post-treatment. Behav Res Ther. 2014;56:1621. [CrossRef]

83. Crowley SI, Lee C, Tseng CY et al. Combinations of bright light, scheduled dark, sunglasses, and melatonin to facilitate circadian entrainment to night shift work. J Biol Rhythms. 2003;18:513-23. [CrossRef] 